\title{
viewpoint
}

\section{The future of agriculture}

\author{
Agricultural knowledge for economically, socially and environmentally sustainable development
}

\author{
Marta G. Rivera-Ferre
}

$\Delta$ t the 2002 World Summit on Sustainable Development held in South Africa, the World Bank (Washington, DC, USA) and the United Nations' Food and Agriculture Organization (FAO, Rome, Italy) announced that they would organize a global consultation process on agricultural science and technology (IAASTD, 2003). They showed remarkable foresight: when the International Assessment of Agriculture, Science and Technology for Development (IAASTD) final reports were approved in April 2008, they were released to media and governments already disturbed about biofuels, increasing food prices, food protests in developing countries, and a general concern about producing enough food to feed the world (IAASTD, 2008).

In a relatively short time, agriculture has once again become the focus of politicians, consumers, scientists and environmentalists. Indeed, the main question that the IAASTD set out to answer, with some foresight, was: "How can we reduce hunger and poverty, improve rural livelihoods, and facilitate equitable, environmentally, socially and economically sustainable development through the generation, access to, and use of agricultural knowledge, science and technology (AKST)?" Now, as the report is published, such topics are not only matters of academic interest, but also issues of increasing economic, political and even strategic importance.

With an intergovernmental governance structure, the IAASTD is agriculture's equivalent to the Intergovernmental Panel on Climate Change (IPCC), with no less a difficult task. At its first meeting as a global consultative process in Ireland in November 2002, the IAASTD brought together about 100 participants from governments, the private sector, non-governmental organizations, farmer and other producer groups, consumers, scientists and international organizations. The goal was to share ideas and views about agriculture and develop a common understanding and vision for the future (IAASTD, 2005).

7 he report sets the scene in which the IAASTD met: "Today there is a world of asymmetric development, unsustainable natural resource use, and continued rural and urban poverty. Generally, the adverse consequences of global changes have the most significant effects on the poorest and most vulnerable, who historically have had limited entitlements and opportunities for growth." It continues, "The pace of formal technology generation and adoption has been highly uneven. Actors within North America and Europe (NAE) and emerging economies who have captured significant economies of scale through formal AKST will continue to dominate agricultural exports and extended value chains. There is an urgent need to diversify and strengthen AKST recognizing differences in agroecologies and social and cultural conditions. The need to re-tool AKST, to reduce poverty and provide improved livelihoods options for the rural poor, especially landless and peasant communities, urban informal and migrant workers, is a major challenge."

\section{In a relatively short time, agriculture has once again become the focus of politicians, consumers, scientists and environmentalists}

The task of gathering information about the various types and methods of agriculture, and assessing them for their ability to produce food in a sustainable manner was an arduous and difficult one. Nevertheless, the long evaluation process has created the basis for making recommendations about the future of agriculture with input from various disciplines, including sociology, agronomy, biology, economy and chemistry. One of the biggest hurdles to drawing meaningful conclusions and making policy recommendations has been the strong political and economic interests that drive agriculture. Differing views of its role in society or its ecological and societal impacts have often coincided with alternative ideas about the fair distribution of resources and sustainable development. The report therefore emphasizes the multifunctionality of agriculture (Fig 1), which is not only about producing food or generating economic income, but also about defining the lives of millions of people and having an important role in mitigating environmental damage.

S ince the start of the industrial revolution, agriculture has undergone a series of important transformations. In Europe and North America, scientific progress, coupled with a demand to feed the rapidly growing industrial and urban populations, has pushed up productivity continuously and has industrialized agriculture to a large extent. By contrast, poorer countries and many small, isolated communities have preserved more traditional farming methods. Consequently, there are now two main models of producing food in the world.

Industrialized agriculture, as the name suggests, is an industry that aims to produce food-in many cases, commodities-as efficiently and cheaply as possible. It not only caters to local consumers, but also aims to contribute to a country's exports and gross 


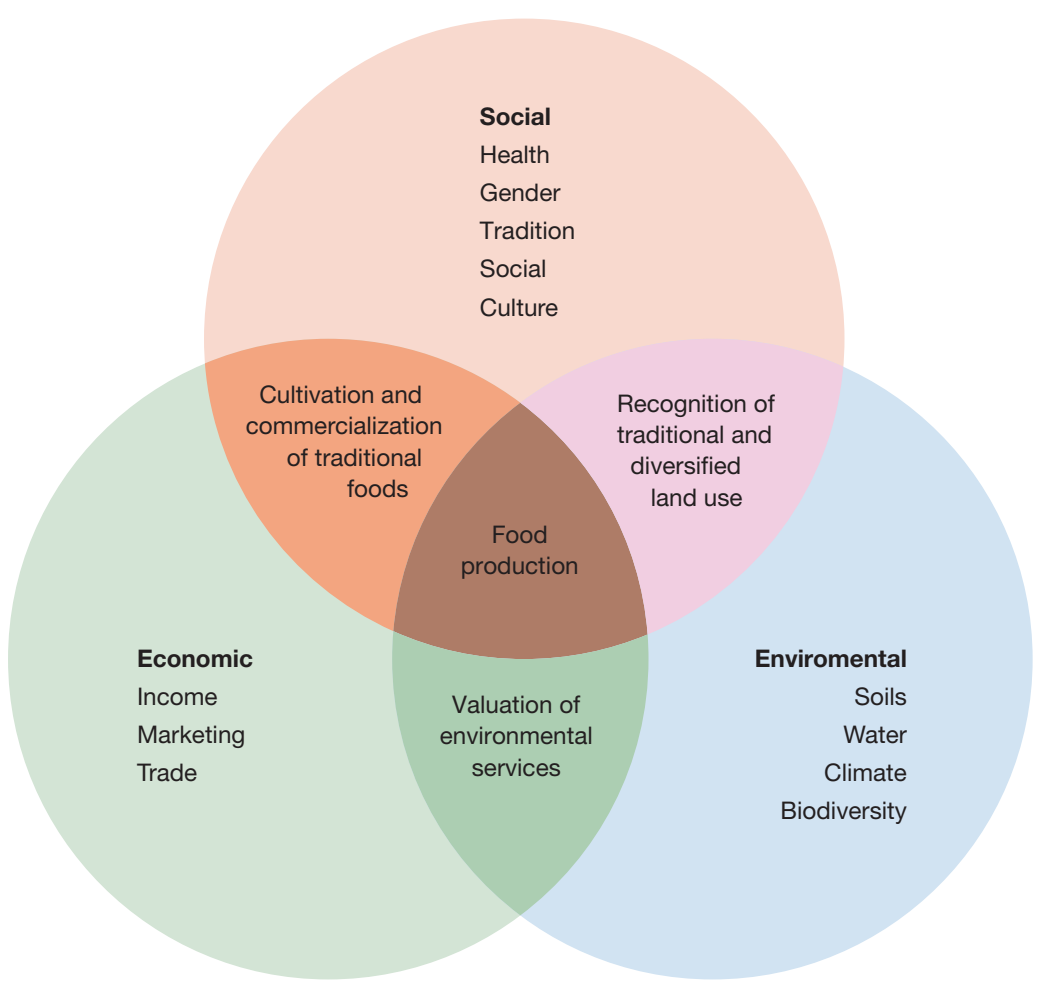

Fig 1 Agriculture and multifunctionality (IAASTD, 2008).

national product. To produce high yields and surpluses, export-oriented agriculture requires the heavy use of sophisticated technology: large farming machinery, artificial fertilizers, pesticides and herbicides, irrigation systems, high-yield hybrid crop varieties and genetically modified crops. These technologies, in turn, depend on research carried out by universities or dedicated research centres and companies, which rely on public and private investments, thus linking AKST to the financial markets. Industrial agriculture uses a top-down methodology that can be adopted anywhere on the planet wherever the necessary environmental conditions-notably soil quality, water quantity and appropriate climate-are met. It is also capital-intensive, as producers have to buy external inputs such as seeds, fertilizers, pesticides, machinery and fuel. However, although industrialized agriculture has markedly increased global food production during the past 100 years, it has also created many problems in terms of environmental degradation, the exclusion of small farmers, consumer safety and public health. This model has also expanded to various poorer countries.
Traditional agriculture, by contrast, mainly serves to feed its local population and seldom contributes to a country's exports. It is labour-intensive rather than technology-dependent and relies on the knowledge developed by local communities that is passed from generation to generation. Traditional agriculture is context-dependent-that is, there are many different forms and methods, which are adapted to local ecosystems and the needs of the local population, and that contribute to so-called endogenous development. Although it does not rely as heavily on fertilizers, pesticides or herbicides as industrialized agriculture does, it too has an impact on the environment and thus needs to improve some practices. Obviously there is a wide range of intermediates between the two forms of agricultural models. No matter the details, both types have advantages and

...agriculture [...] is not only about producing food or generating economic income, but also about defining the lives of millions of people... disadvantages, and different impacts on the environment and society.

During the last century, agricultural research, technological development, and public and private investments have been focused on the industrialized approach to agriculture, as the overall aim has beenand still is- to increase production and productivity. The result has been an impressive increase in food production that has even surpassed human population growth: from 1971 to 2005, food production increased by $61 \%$ (www.fao.org/statistics), whereas the world population grew by 55\% (www. census.gov/). During the same period, the purchasing power parity-and thus the potential ability to buy food-increased by $274 \%$ (www.imf.org). Scientists, farmers, breeders and the chemical industry have continuously innovated and improved to reduce farm gate prices-the price of the product available at the farm-while externalizing environmental and societal impacts, which are not included in the final price of agricultural products.

$\mathrm{R}$ esearch and development have paid much less attention to the-albeit often unintended-social and environmental consequences of increased food production. Despite an abundance of food in developed countries, more than 854 million people still suffer from malnutrition and undernutrition (FAO, 2006), whereas the number of obese people has increased, ironically, mainly among the poor (Young, 2004; Prentice, 2006). The Indian economist and philosopher Amartya Sen, who received the Nobel Prize for economics in 1998, emphasized that food security is not only a matter of producing enough food to eat, but also of making the food available to those who need it (Sen, 1981).

Furthermore, industrial agriculture has an enormous environmental impact. It directly contributes $14 \%$ of the total manmade emissions of greenhouse gasesmainly methane and nitrous oxide-while changes in land use contribute a further $18 \%$ (Stern, 2007), usually owing to deforestation in order to increase areas of arable land. Other environmental impacts include land erosion and degradation, salinization of soils owing to over-irrigation, water pollution and eutrophication-the pollution of land and water ecosystems with nitrogen and phosphorous fertilizers. Furthermore, industrialized food production has also had a serious impact on biodiversity; many 
marine ecosystems are on the verge of collapse as a result of overfishing, while changes on land have destroyed or reduced land-based ecosystems such as rainforests or grasslands. Moreover, most of the important staple crops used throughout the world-maize, wheat or rice-are based on only a few elite varieties that have replaced locally grown ones. This represents not only a loss of biodiversity, but also a problem for breeding programmes, as the loss of varieties also means the loss of potentially useful alleles.

\section{It seems sadly obvious that agriculture [...] cannot feed the human population, fulfil our energy needs, and preserve the environment and biodiversity all at the same time}

Industrial agriculture has also had a direct impact on human health, not only in terms of undernutrition, malnutrition and food safety, but also for the emergence of infectious diseases. Perhaps more seriously, the use of antibiotics in livestock farming to increase growth has been one of the main factors contributing to the increase in antibiotic resistance among bacterial pathogens, including resistance to vancomycin, which is a last-line antibiotic used only to treat serious infections of antibiotic-resistant bacteria. Similarly, pesticides constitute a major health problem, causing death, acute and chronic neurotoxicity, lung damage, chemical burns, infant methemoglobinaemia, various cancers, immunological abnormalities, and adverse reproductive and developmental effects (Weisenburger, 1993; Eddleston et al, 2002). Each year, hundreds of thousands of farmers, mostly in developing countries, are affected by exposure to pesticides; however, the figures should be interpreted with caution, as not all deaths are due to occupational poisoning, but include self-ingestion, accidental ingestion and homicides (Wilson \& Tisdell, 2001).

Growing interest in biofuels as an alternative to fossil fuels has also contributed to the marked increase in agricultural interest during the past few years. The idea that

\section{science \& society}

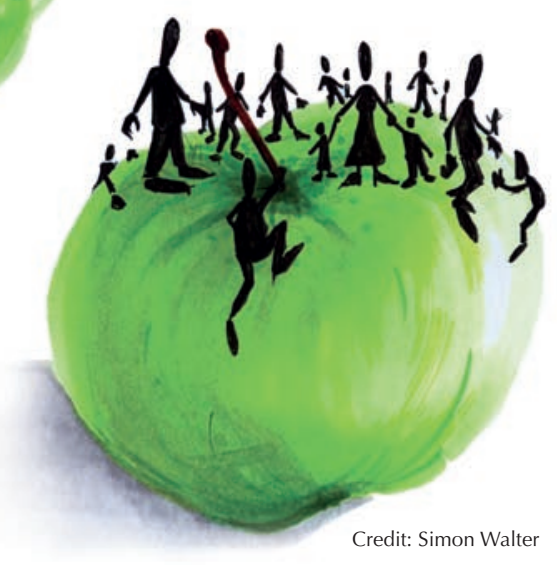
viate global climate change and further spur economic growth in the agricultural sector, seemed to be a win-win situation (Ruth, 2008). However, it has become eminently clear that current biofuels are not a viable option: the recent increase in demand for biofuels contributed to the rise in global food prices, causing famines and protests in poorer countries. It seems sadly obvious that agriculture-even with improved 'energy crops' and new technologies to convert organic material into biofuels-cannot feed the human population, fulfil our energy needs, and preserve the environment and biodiversity all at the same time.

T hese developments highlight three types of disconnection in the current situation: between agriculture and the environment, as food and commodities production becomes more important than biodiversity or ecological preservation; between producers and consumers, the latter of whom no longer know where their food comes from or how it is produced; and between policies and their consequences, such as the tax benefits for growing biofuels in the USA or EU/US policies to promote industrial agriculture at the expense of small farmers and developing countries. To overcome this situation, the IAASTD has stated that 'business as usual' is not an option. Instead, we need an inclusive strategy to improve on agriculture that adds different actors and opinions, rather than reduces. Some of the crucial recommendations are to adopt 'agroecological' strategies; to create better opportunities for farmers and rural workers in developing countries; to strengthen the role of women; to integrate traditional knowledge; and to involve social scientists in policy formulations (Stokstad, 2008).
A groecology applies ecological conment of agricultural systems in order to fulfil environmental, social and economic expectations: sustainable production, healthy environments, and viable food and farming communities. It uses a multidisciplinary, whole-systems approachbased on traditional knowledge, alternative forms of agriculture and local experienceswhich integrates the social and cultural aspects of agriculture. Some examples proposed by the IAASTD include improving low-impact practices and providing incentives for the sustainable management of water, livestock, forests and fisheries. Various critics maintain that sustainable agricultural practices are less productive than conventional ones and would therefore not be able (Borlaug, 2000; Trewavas, 2004). Although this assertion is a matter of discussion (Pretty, 1999; Badgley et al, 2007), as many types of sustainable agriculture exist in many different contexts, it is clear that sustainable agriculture has been much less researched than industrial agriculture during the past 40 years, which gives it a considerable margin for improvement.

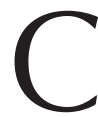
reating better opportunities for poor farmers and rural labourers involves including their expectations and experience not only in research and development, but also in policy-making and political decisions. As some of the main stakeholders in agriculture, they should be allowed to influence decisions about the use and management of natural resources, access to land, intellectual property rights, trade priorities and environmental protection measures. Small-scale farmers would cepts to the design and manageto feed the world's future human population, 


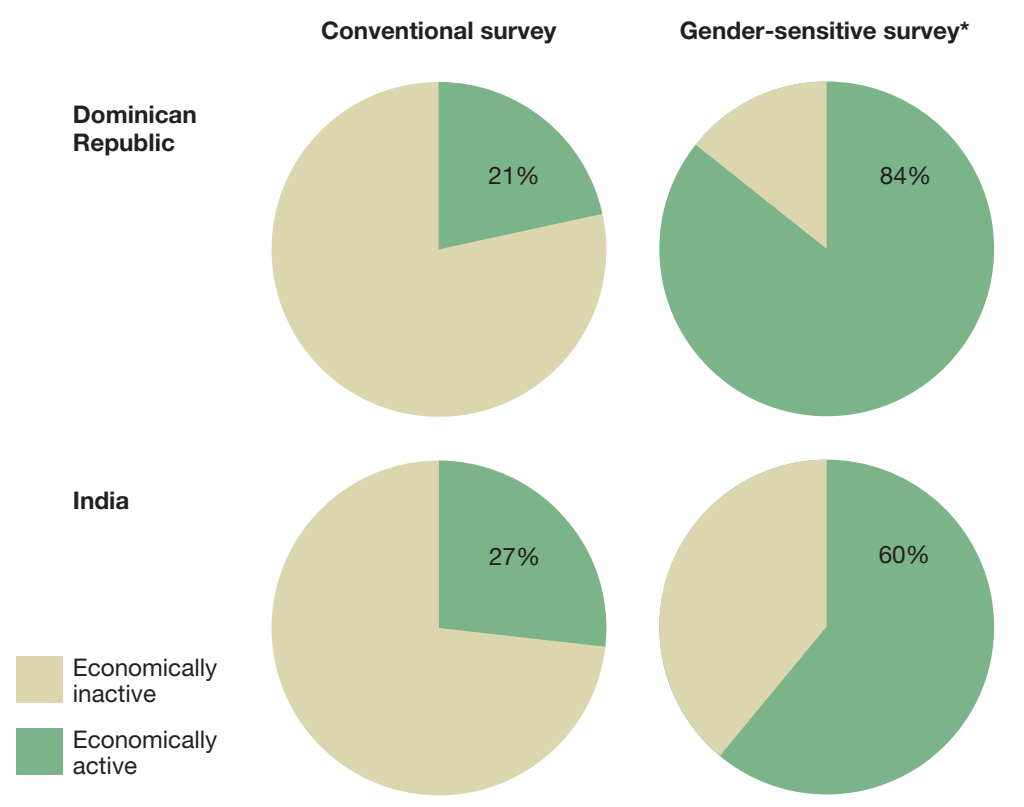

Fig 2 | Counting women's labour in agriculture (IAASTD, 2008). The asterisk indicates the inclusion of gardening and animal care for both countries, and fuelwood collection for India.

clearly benefit from more research dedicated to their cause, access to knowledge, technology and credit, and, critically, from more political influence. Most importantly, farmers need to be able to get fair prices for their products in both local and global markets. They need legal security to guarantee access to land, water and natural resources, and fair access to intellectual property. Moreover, creating more equity in agriculture would mean introducing technology to, and improving education in, poor areas.

$\mathrm{T}$ he current system used to value productive activities focuses largely on those that create monetary assets; the labour and knowledge of women, which are essential to support family households and rural communities, are not taken into account. However, the participation of women is particularly important. Although women are involved in all agricultural and post-harvest activities, they are predominantly among the poorest, particularly in developing countries. Most of these women do not have access to natural resources, education or training, while their labour and knowledge is largely ignored (Fig 2). In addition to housekeeping and child rearing, women are usually responsible for carrying water and gathering fuel wood, planting and transplanting, weeding, harvesting, picking fruits and vegetables, small livestock rearing, and post-harvest operations such as threshing, seed selection and storage. In many rural areas, they are also recognized as the guardians of biodiversity. Integrating their knowledge and labour is essential to achieve the goals of development and sustainability stated in the IAASTD's rationale. Indeed, if women's labour were considered as productive work, economic statistics would change markedly (Fig 2). This suggests that major changes to our consideration of what are productive activities are required, and will involve greater collaboration with women to understand their traditional knowledge, as well as facilitating their access to formal education. Moreover, it requires changing political structures to allow their participation in decision-making processes, including in science policy.

\section{...sustainable agriculture has been much less researched than industrial agriculture during the past 40 years, which gives it a considerable margin for improvement}

"AKST arrangements involve ethical choices and value judgements. In some cases they have excluded or marginalized key actors, such as small-scale farmers, with preference being given to short-term over longer-term considerations. Some judgements have been privileged over others in AKST decision making. They have helped push formal AKST along certain pathways to the neglect of other well-evidenced options, some originating in traditional knowledge or civil society experience, that are more focused on the multiple roles of agriculture. Strengthening public support for empowering the organizations of farmers and other community-based groups can increase poor people's influence in collaborative AKST arrangements and decision making" (IAASTD, 2008).

$\mathrm{T}$ raditional and indigenous knowledge, as well as the identities and practices of indigenous and local communities, are recognized under the UN Convention on Biological Diversity as relevant for the conservation and sustainable use of biodiversity (CBD, 1993). To meet the challenge of feeding a projected nine billion people in a sustainable manner will therefore require using all types of knowledge and technology, and the involvement of all parties. A necessary first step is to acknowledge the fact that indigenous knowledge and traditional agriculture have been discriminated against and that their potential contribution to development and environmental sustainability have not been considered in agriculture, but rather spurned as primitive and inefficient.

Furthermore, agricultural research, through increasing participation and democratic governance, can help to overcome the political constraints faced by small-scale farmers. If most research and development continues to create sophisticated tools and crops that only farmers in rich countries are able to afford, it will further neglect the potential of poor and small-scale farmers. Alternatively, if these farmers can contribute their extensive knowledge about local conditions, ecosystems and practices, then agriculture as a whole could be refined and tailored to specific locations. Just as personalized medicine is the new dream of health officials, so context-dependent agriculture could become a productive reality of mutual benefit to society and farmers. Finding new ways to manage natural resources, for example, could benefit enormously from greater communication between researchers and farmers with traditional and community knowledge. Once the role and value of traditional knowledge in improving livelihoods is accepted, scientists from both developed 
and developing countries should collaborate with small-scale farmers and farmers in poor countries, rather than deciding for them what technologies to adopt or what seeds to plant.

$\mathrm{D}$ uring the IAASTD assessment process, it also became clear that the methodologies used by other scientific fields-notably in the social sciences-provide helpful tools to mitigate the negative effects of industrialized agriculture. Social scientists have been analysing the social (Barnes, 1971; Friedland et al, 1978; Goodman et al, 1987; Friedmann \& McMichael, 1989; Molnar \& Kinnucan, 1989; Bonano, 1991; Bonano et al, 1994; McMichael, 1994) and environmental (Pimentel et al, 1973; Buttel \& Larson, 1979; Dunlap \& Martin, 1983; Coughenour, 1984) effects of agriculture since the 1970 s. Perhaps, if we had paid attention to their analyses and collaborated with them earlier, we would be in a different situation today. The IAASTD has analysed most of these perspectives and suggests that more interdisciplinary work should be undertaken to improve the tools used by social and natural scientists to evaluate the impact of agriculture on society. Integrating the expertise from various fields will help to develop solutions that increase productivity, protect natural resources and livelihoods, and minimize the negative effects of agriculture on the environment and humans.

In many cases, finding new solutions to existing problems is not only a matter of generating or using scientific knowledge, but also requires policy changes. Clearly AKST alone cannot solve the major problems, which are often caused by complex political and social dynamics. However, it can make an important contribution to meeting the goals of development and sustainability. The natural sciences can inform policy changes, whereas the political, social and economic sciences have a lot to say about how these changes could be organized; for example, how to prepare a legal framework that would strengthen local markets and improve food safety and quality. They can also help to focus the natural sciences on achieving these objectives while minimizing the social and environmental impacts of the agriculture.

To ensure further development and meet sustainability goals, the IAASTD distinguishes two areas of action: improving technologysuch as the improvement of crops or livestock, including local autochthonous breeds or

\section{Just as personalized medicine is the new dream of health officials, so personalized context-dependent agriculture could become a productive reality of mutual benefit to society and farmers}

sustainable practices for using water, energy and other natural resources - and creating an organizational infrastructure to develop policy tools. How these two areas interact can be exemplified in the case of human health, which can be improved through diversifying diets and enhancing their nutritional value through improved technologies and processes to preserve and distribute food, and also through better health policies and healthcare systems. Another example is sustainable agriculture itself: it not only requires research to increase productivity and to improve management, but also institutional arrangements to support it, for example, by internalizing the environmental and social costs of industrial agriculture.

$\mathrm{P}$ utting into practice the new and innovative approaches suggested by the IAASTD is not an easy task. Experimental scientists are not used to working with farmers or small communities; they are not used to bottom-up approaches either, and tend to rely on empirical results from laboratory experiments or field trials rather than on indigenous knowledge. However, although the Cartesian principle of reductionism on which modern science relies has contributed greatly to the advance of science, it is clearly not suitable to answer the questions raised by the IAASTD, which will also require more holistic approaches. In this sense, traditional knowledge is more pragmatic, dynamic and probably more suited to addressing some relevant problems. Participatory collaboration in generating knowledge, technology development and innovation has been shown to add value to science-based technology development (Nederlof et al, 2004; Ingram, 2008). It is therefore up to experimental scientists to acknowledge and combine other types of knowledge and to promote participation.

As mentioned earlier, industrial agriculture has made considerable progress during the past 100 years in increasing food production. Yet, despite all these advances and the agricultural knowledge generated during this time, we still need to find answers to the question raised by the IAASTD. This represents a major challenge for science; one that becomes increasingly relevant in the light of current high prices for energy and food and a growing world population. It is a challenge that cannot be met without the active participation of scientists from many disciplines, as well as farmers and the guardians of traditional knowledge. Let us hope, then, that neither the various political and economic interests, nor reductionist scientific attitudes, cause the efforts made by the IAASTD to be ignored.

\section{REFERENCES}

Badgley C, Moghtader J, Quintero E, Zakem E, Chappell MJ, Avilés-Vázquez K, Samulon A, Perfecto I (2007) Organic agriculture and the global food supply. Renewable Agriculture and Food Systems 22: 86-108

Barnes P (1971) Vanishing small farmer. New Repub 164: $21-24$

Bonano A (1991) The restructuring of the agricultural and food system: social and economic equity in the reshaping of the Agrarian Question and the Food Question. Agric Human Values 8: 72-82

Bonano A, Busch L, Friedland WH, Gouveia L, Mingione E (Eds) (1994) From Columbus to ConAgra: The Globalization of Agriculture and Food. Lawrence, KS, USA: University Press of Kansas

Borlaug NE (2000) Ending world hunger. The promise of biotechnology and the threat of antiscience zealotry. Plant Physio/ 124: 487-490

Buttel FH, Larson OW (1979) Farm size, structure and energy intensity: an ecological analysis of U.S. agriculture. Rural Sociol 44: 471-478

CBD (1993) Convention on Biological Diversity. Montreal, Canada: Secretariat of the Convention on Biological Diversity

Coughenour CM (1984) Social ecology and agriculture. Rural Socio/ 49: 1-22

Dunlap RE, Martin KE (1983) Bringing environment into the study of agriculture: observations and suggestions regarding the sociology of agriculture. Rural Sociol 48: 201-218

Eddleston $\mathrm{M}$ et al (2002) Pesticide poisoning in the developing world - a minimum pesticides list. Lancet 360: 1163-1167

FAO (2006) The State of Food Insecurity in the World 2006. Eradicating World Hunger-Taking Stock Ten Years After the World Food Summit. Rome, Italy: Food and Agriculture Organization Friedland WH, Barton AE, Thomas RJ (1978) Manufacturing Green Gold: The Conditions and Social Consequences of Lettuce Harvest Mechanization. Davies, CA, USA: Department of Applied Behavioral Sciences, University of California, Davies

Friedmann H, McMichael P (1989) Agriculture and the state system; the rise and decline of national agricultures, 1870 to the present. Sociologia Ruralis 29: 93-117

Goodman D, Sorj B, Wilkinson J (1987) From Farming to Biotechnology: A Theory of AgroIndustrial Development. Oxford, UK: Basil Blackwell 
IAASTD (2003) An Assessment of Agricultural Science and Technology for Development. Washington, DC, USA: International Assessment of Agricultural Knowledge, Science and Technology for Development. www.agassessment.org/

IAASTD (2005) About IAASTD. Overview and Structure. Washington, DC, USA: International Assessment of Agricultural Knowledge, Science and Technology for Development. www.agassessment.org/

IAASTD (2008) Agriculture at a Crossroads: The Synthesis Report. Washington, DC, USA: International Assessment of Agricultural Knowledge, Science and Technology for Development. www.agassessment.org/

Ingram J (2008) Agronomist-farmer knowledge encounters: an analysis of knowledge exchange in the context of best management practices in England. Agric Human Values 25: 405-418

McMichael P (Ed) (1994) The Global Restructuring of Agro-Food Systems. Ithaca, NY, USA: Cornell University Press

Molnar JJ, Kinnucan H (Eds) (1989) Biotechnology and the New Agricultural Revolution. Boulder, CO, USA: Westview

Nederlof ES, Tossou R, Sakyi-Dawson O, Kossou DK (2004) Grounding agricultural research in resource-poor farmers' needs: a comparative analysis of diagnostic studies in Ghana and Benin. NJAS-Wageningen Journal of Life Sciences 52: 421-442

Pimentel D, Hurd LE, Bellalti AC, Forster HJ, Oka IN, Sholes OD, Whitman RJ (1973) Food production and the energy crisis. Science 182: 443-449

Prentice AW (2006) The emerging epidemic of obesity in developing countries. Int / Epidemiol 35: 93-99

Pretty J (1999) Can sustainable agriculture feed Africa? New evidence on progress, processes and impacts. Environment, Development and Sustainability 1: 253-274

Ruth L (2008) Bio or bust. EMBO Rep 9: 130-133

Sen A (1981) Ingredients of famine analysis: availability and entitlements. Q J Econ 96: 433-464

Stern N (2007) The Economics of Climate Change; The Stern Review. Cambridge, UK: Cambridge University Press

Stokstad E (2008) Duelling visions for a hungry world. Science 319: 1474-1476

Trewavas A (2004) A critical assessment of organic farming-and-food assertions with particular respect to the UK and the potential environmental benefits of no-till agriculture. Crop Prot 23: 757-781

Weisenburger DD (1993) Human health effects of agrichemical use. Hum Path 24: 571-576
Wilson C, Tisdell C (2001) Why farmers continue to use pesticides despite environmental, health and sustainability costs. Ecol Econ 39: 449-462

Young EM (2004) Globalization and food security: novel questions in a novel context? Progress in Development Studies 4: 1-21

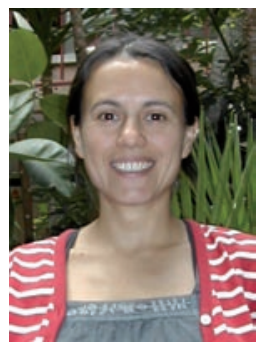

Marta G. Rivera-Ferre is at the Animal and Food Sciences Department at the Autonomous University of Barcelona, Spain.

E-mail: martaguadalupe.rivera@uab.es

doi:10.1038/embor.2008.196

Published online 17 October 2008 